\title{
Patient characteristics associated with enrolment under voluntary programs implemented within fee-for-service systems in British Columbia and Quebec: a cross-sectional study
}

\author{
M. Ruth Lavergne PhD, Caroline King PhD, Sandra Peterson MSc, Leora Simon MSc, \\ Catherine Hudon MD PhD, Christine Loignon PhD, Rita K. McCracken MD PhD, Austyn Brackett, \\ Kim McGrail PhD, Erin Strumpf PhD; for the QC-BC Patient Enrolment Project Team*
}

\section{Abstract}

Background: There is a paucity of information on patient characteristics associated with enrolment under voluntary programs (e.g. incentive payments) implemented within fee-for-service systems. We explored patient characteristics associated with enrolment under these programs in British Columbia and Quebec.

Methods: We used linked administrative data and a cross-sectional design to compare people aged 40 years or more enrolled under voluntary programs to those who were eligible but not enrolled. We examined 2 programs in Quebec (enrolment of vulnerable patients with qualifying conditions [implemented in 2003] and enrolment of the general population [2009]) and 3 in BC (Chronic disease incentive [2003], Complex care incentive [2007] and enrolment of the general population [A GP for Me, 2013]). We used logistic regression to estimate the odds of enrolment by neighbourhood income, rural versus urban residence, previous treatment for mental illness, previous treatment for substance use disorder and use of health care services before program implementation, controlling for characteristics linked to program eligibility.

Results: In Quebec, we identified 1569010 people eligible for the vulnerable enrolment program (of whom 505869 [32.2\%] were enrolled within the first $2 \mathrm{yr}$ of program implementation) and 2394923 for the general enrolment program (of whom 352380 [14.7\%] were enrolled within the first $2 \mathrm{yr}$ ). In BC, we identified 133589 people eligible for the Chronic disease incentive, 47619 for the Complex care incentive and 1349428 for A GP for Me; of these, 60764 (45.5\%), 28273 (59.4\%) and 1066714 (79.0\%), respectively, were enrolled within the first 2 years. The odds of enrolment were higher in higher-income neighbourhoods for programs without enrolment criteria (adjusted odds ratio [OR] comparing highest to lowest quintiles 1.21 [95\% confidence interval (Cl) 1.20-1.23] in Quebec and 1.67 [95\% Cl 1.64-1.69] in BC) but were similar across neighbourhood income quintiles for programs with health-related eligibility criteria. The odds of enrolment by urban versus rural location varied by program. People treated for substance use disorders had lower odds of enrolment in all programs (adjusted OR 0.60-0.72). Compared to people eligible but not enrolled, those enrolled had similar or higher numbers of primary care visits and longitudinal continuity of care in the year before enrolment.

Interpretation: People living in lower-income neighbourhoods and those treated for substance use disorders were less likely than people in higher-income neighbourhoods and those not treated for such disorders to be enrolled in programs without health-related eligibility criteria. Other strategies are needed to promote equitable access to primary care.

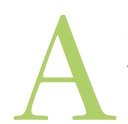

longitudinal relationship between patients and providers is central to continuity and coordination of primary care. ${ }^{1,2}$ Formal enrolment with providers or places of care (also called rostering or empanelment) is a feature of high-performing primary care, facilitating proactive prevention, chronic disease management and qualityimprovement activities. ${ }^{3}$ In many health care systems, patient enrolment is documented as part of capitated payment models. ${ }^{4-6}$ In contrast, under fee-for-service payment (which is the dominant payment model in Quebec and British Columbia), enrolment is not required for a physician to receive payment for services; although primary care providers may maintain a patient panel, and patients may have a regular place they go to for care, this is not formally documented to payers or system administrators.

Competing interests: None declared.

*The list of members appears at the end of the article.

This article has been peer reviewed.

Correspondence to: M. Ruth Lavergne, ruth_lavergne@sfu.ca CMAJ Open 2022 February 1. DOI:10.9778/cmajo.20210043 
From 2003 to 2013, both Quebec and BC implemented enrolment programs within fee-for-service whereby physicians could receive payments over and above regular fee-forservice billings in exchange for a commitment to providing longitudinal care for designated patients. In Quebec, annual payments were introduced first for patients with chronic conditions and those more than 70 years of age (vulnerable enrolment), ${ }^{7}$ and then for the general population (general enrolment $)^{8}$ (Table 1). In British Columbia, payments took the form of additional fee codes billable for patients with chronic conditions (Chronic disease incentive ${ }^{9}$ and Complex care incentive ${ }^{10}$ ) and subsequently a suite of payment incentives for physicians who agreed to provide longitudinal care to a panel of patients (A GP for Me, or Attachment initiative). ${ }^{11}$

It is important to understand the characteristics of people enrolled under such programs, particularly as barriers to primary care access have been observed by income, ${ }^{13,14}$ by rural versus urban residence,,$^{15}$ and among people with mental illness or a substance use disorder. ${ }^{16-18}$ As the risk of developing chronic conditions is associated with socioeconomic status, ${ }^{19,20}$ programs with health-related enrolment criteria such as having 1 or more chronic conditions may improve access among people of lower socioeconomic status. On the other hand, enrolment programs open to the general population may compound better access to primary care already observed among people of higher socioeconomic status. ${ }^{21}$ For example, in Ontario, enrolment in capi- tated models was found to be lower in the lowest income group, ${ }^{22-24}$ and a study of a centralized waiting list for a primary care physician in Quebec showed that, although payments were higher for enrolling patients with chronic health conditions, most people enrolled through this mechanism were healthy. ${ }^{25,26}$

There is a paucity of information on characteristics associated with enrolment under voluntary programs implemented within fee-for-service systems, as in BC and Quebec. We compared the characteristics of enrolled people and people who were eligible but not enrolled, examining differences in the odds of enrolment by neighbourhood income, location of residence (rural v. urban), previous treatment for a mental illness or substance use disorder, and use of health care services before program implementation.

\section{Methods}

\section{Study design and setting}

The enrolment programs studied were introduced in BC and Quebec over a period of 11 years (2003-2013). We adopted the same cross-sectional design to study each program, examining a period of 2 years after program implementation to identify people enrolled as well as people eligible before implementation but unenrolled within the first 2 years. We also examined use of health care services in the year before program implementation, so the data cover the period from

Table 1: Description of enrolment programs implemented within fee-for-service systems in Quebec and British Columbia

\begin{tabular}{|c|c|c|c|c|c|}
\hline \multirow[b]{2}{*}{ Variable } & \multicolumn{2}{|c|}{$\begin{array}{c}\text { Quebec; name of program (date of } \\
\text { implementation) }\end{array}$} & \multicolumn{3}{|c|}{ British Columbia; name of program (date of implementation) } \\
\hline & $\begin{array}{l}\text { Vulnerable enrolment } \\
\quad(\text { Jan. } 1,2003)^{*}\end{array}$ & $\begin{array}{l}\text { General enrolment } \\
\quad \text { (Jan. 1, 2009) }\end{array}$ & $\begin{array}{l}\text { Chronic disease } \\
\text { incentive } \\
\text { (Sept. 1, 2003) }\end{array}$ & $\begin{array}{l}\text { Complex care } \\
\text { incentive } \\
\text { (Apr. 1, 2007) }\end{array}$ & $\begin{array}{l}\text { A GP for } \mathrm{Me}^{11} \\
(\text { Apr. 1, 2013) }\end{array}$ \\
\hline $\begin{array}{l}\text { Criteria for } \\
\text { enrolment }\end{array}$ & $\begin{array}{l}\text { - Chronic conditions, } \\
\text { age }>70 \mathrm{yr}\end{array}$ & - None & $\begin{array}{l}\text { - Diabetes, } \\
\text { congestive heart } \\
\text { failure } \\
\text { - List of eligible } \\
\text { conditions } \\
\text { expanded in } 2006\end{array}$ & $\begin{array}{c}\bullet \\
\text { conditions }\end{array}$ & $\begin{array}{l}\text { - None; all primary } \\
\text { care physicians } \\
\text { and their patients }\end{array}$ \\
\hline $\begin{array}{l}\text { Physician } \\
\text { responsibilities } \\
\text { for enrolled } \\
\text { patients }\end{array}$ & \multicolumn{2}{|c|}{$\begin{array}{l}\text { - Formal enrolment between patient and } \\
\text { physician through signed contract } \\
\text { - Physician agrees to take charge of patient } \\
\text { regularly and provide required follow-up care }\end{array}$} & $\begin{array}{l}\text { Physician bills } \\
\text { code accepting } \\
\text { responsibility for } \\
\text { chronic disease } \\
\text { management for } \\
1 \text { yr }\end{array}$ & \multicolumn{2}{|c|}{$\begin{array}{l}\text { - Physician bills code indicating willingness } \\
\text { to provide "full-service family practice" and } \\
\text { confirm relationship with patient through } \\
\text { "standardized conversation" }\end{array}$} \\
\hline $\begin{array}{l}\text { Annual payment } \\
\text { amount per } \\
\text { patient† }\end{array}$ & $\begin{array}{l}\text { - } \$ 14-\$ 21 \text { (varies } \\
\text { based on practice } \\
\text { setting) } \\
\text { - Subsequently } \\
\text { increased to } \\
\$ 35-\$ 75^{12} \\
\text { - Enables billing of } \\
\text { additional fee codes }\end{array}$ & $\begin{array}{l}\text { - } \$ 7-\$ 11 \text { (varies } \\
\text { based on practice } \\
\text { setting) } \\
\text { - Enables billing of } \\
\text { additional fee } \\
\text { codes }\end{array}$ & - $\$ 75$ & - $\$ 315$ & $\begin{array}{l}\text { - } \$ 0 \text { opt-in, but } \\
\text { enables billing of } \\
\text { additional fee } \\
\text { codes }\end{array}$ \\
\hline
\end{tabular}


2002 to 2015. As uptake increased gradually over the first year for all programs, ${ }^{27,28}$ examining 2 years for each program allowed us to compare across programs at the same stage of implementation.

The enrolment programs in Quebec and BC differ with respect to eligibility criteria, requirements of enrolment and payment mechanisms (Table 1), but all are voluntary in that physicians choose whether they want to participate in the programs and which patients they bill codes for. None of the programs include negation or penalties if patients seek care elsewhere. In BC, programs are open to all fee-for-service primary care physicians. In Quebec, enrolment programs were also open to all primary care physicians, with eligibility depending on patient characteristics as described in Table 1. Primary care physicians working in Family Medicine Groups, an interdisciplinary team model, could enrol all patients regardless of their age or health status.

\section{Population}

The study populations included people registered for health insurance for more than $75 \%$ of days in the 2 years before and the 2 years after program implementation who were aged 40 years or more (ages more likely to use primary care regularly) and who met the eligibility criteria for each program (based on diagnosis codes in physician and hospital records [Appendix 1, Table S1, available at www.cmajopen.ca/content/ 10/1/E64/suppl/DC1]) in the year before program implementation (Table 2). People who moved or died (and so were registered for $<75 \%$ of days) were excluded. We excluded people with missing age or sex, with a recorded age of more than 120 years, or who used services that indicated they were residents of a long-term care facility.

\section{Data sources}

Administrative databases were accessed and housed separately within provinces, although measures and analysis were the same. We used databases maintained by the Quebec Ministry of Health and Social Services and the provincial health insurer (provided through the National Institute for Excellence in Health and Social Services) and the BC Ministry of Health (provided through Population Data BC) ${ }^{29-34}$ (Appendix 1, Table S2). Databases included central demographic files maintained by provincial insurers (consolidation file in $\mathrm{BC}$ and Le Fichier d'inscription des personnes assurées in Quebec), billing data from fee-for-service practitioners (Medical Services Plan payments information file in BC and Régie de l'assurance maladie in Quebec), hospital discharges (Discharge Abstract Database in BC and MED-ÉCHO in Quebec), information about emergency department visits (National Ambulatory Reporting Care System in BC and Banque de données communes des urgences in Quebec) and prescription data (PharmaNet, BC only).

\section{Measures}

For all programs except A GP for Me, the intervention (enrolled) population included people who had a billing record indicating enrolment within the first 2 years of program implementation, and the comparison population, those who were eligible but not enrolled within the first 2 years. The mechanism of confirming enrolment between physicians and provincial funders was submission of fee items; thus, enrolment is captured completely in our data.

A GP for Me is a physician-level program in which physicians opt in for all patients. For analysis of this program, the intervention population was people who received a majority of their care from an opted-in physician. We restricted this analysis to people with 3 or more primary care visits so we could identify a majority source of care.

All measures of patient characteristics were captured before program implementation and patient enrolment. Patient age and sex or gender are collected at time of registration for provincial insurance programs. The latter field is labelled "gender" in BC and "sex" in Quebec; in both cases, only binary "male" and "female" options are provided. Whether this reflects gender, sex at birth or legal sex cannot be determined.

\begin{tabular}{|c|c|c|c|}
\hline \multirow[b]{2}{*}{ Population } & Quebec & \multicolumn{2}{|c|}{ British Columbia } \\
\hline & $\begin{array}{l}\text { Vulnerable enrolment and } \\
\text { general enrolment }\end{array}$ & $\begin{array}{l}\text { Chronic disease incentive } \\
\text { and Complex care incentive }\end{array}$ & A GP for $\mathrm{Me}$ \\
\hline Intervention & $\begin{array}{l}\text { Patients for whom relevant } \\
\text { billing codes were } \\
\text { submitted within the first } \\
2 \text { yr of implementation }\end{array}$ & $\begin{array}{l}\text { Patients with qualifying chronic } \\
\text { conditions in the year before } \\
\text { the policy change for whom the } \\
\text { relevant code was billed within } \\
\text { the first } 2 \text { yr of implementation }\end{array}$ & $\begin{array}{l}\text { Patients who received the } \\
\text { majority of their care from } \\
\text { physicians who opted into the } \\
\text { program* }\end{array}$ \\
\hline Comparison & $\begin{array}{l}\text { Patients who were eligible } \\
\text { but were not enrolled } \\
\text { within the first } 2 \mathrm{yr} \text { of } \\
\text { implementation }\end{array}$ & $\begin{array}{l}\text { Patients with qualifying chronic } \\
\text { conditions in the year before } \\
\text { the policy change with no code } \\
\text { billed within the first } 2 \text { yr of } \\
\text { implementation }\end{array}$ & $\begin{array}{l}\text { Patients with } \geq 3 \text { visits who } \\
\text { received the majority of their } \\
\text { care from a physician who did } \\
\text { not opt in }\end{array}$ \\
\hline
\end{tabular}


We used the Elixhauser Comorbidity Index ${ }^{35}$ to count the number of comorbid conditions.

We used the census enumeration area of the patient's residence to assign neighbourhood income quintile and to classify residence by rurality, employing the Statistics Canada Statistical Area Classification type metropolitan influenced zones. ${ }^{36}$ We compared census metropolitan areas, census agglomerations and areas with strong metropolitan influence (which we termed "smaller urban") and areas with moderate to no metropolitan influence (which we termed "rural/remote"). In BC, we were also able to identify people whose prescription coverage indicated they received income assistance.

We identified people who received mental health services (International Classification of Diseases, Ninth Revision [ICD-9] codes 295-302, 306-319, 50B [BC only]; enhanced Canadian version of International Statistical Classification of Diseases and Related Health Problems, Tenth Revision codes F20-F99, excluding F55) or services for substance use disorders (ICD-9 codes 291, 292, 303-305, 980; International Statistical Classification of Diseases and Related Health Problems, Tenth Revision codes F10F16, F18-F19 and T51) based on service use (1 hospital admission or 2 physician claims for mental health services, 1 hospital admission or 1 physician claim for substance use services) in the year before program implementation.

We counted the number of ambulatory physician visits with a primary care physician and of emergency department visits in the year before program implementation. Ambulatory visits were based on unique physician-patient-date combinations with a claim specialty of primary care that occurred in an office, home or other ambulatory location (excluding hospital, emergency department and long-term care) and excluding laboratory claims and diagnostic tests. We measured longitudinal continuity of care as the proportion of primary care visits with the physician seen most often (usual provider continuity).

\section{Statistical analysis}

We describe age, sex or gender, chronic health conditions, neighbourhood income quintile, urban or rural residence, and use of health care services for mental illness and substance use disorders among patients eligible for the programs as well as for the entire provincial population aged 40 years or more, presenting counts and percentages, or means and standard deviations as appropriate. We compared people enrolled and people who were eligible but not enrolled with respect to these characteristics and reported standardized differences. ${ }^{37}$

We constructed logistic regression models for each enrolment program separately, estimating odds of enrolment by neighbourhood income quintile, rurality, use of health care services for mental illness and substance use disorders, and use of health care services in the year before enrolment. We present bivariable (unadjusted) and multivariable odds ratios (ORs) adjusted for patient age, sex or gender, and number of comorbidities.

\section{Ethics approval}

This project was reviewed and approved by the McGill University Research Ethics Board (A05-B33-17B), the University of British Columbia/Simon Fraser University Harmonized Research Ethics Board (H17-01497) and the Comité d'éthique de la recherche - Éducation et sciences sociales, Université de Sherbrooke (2017-1655/Strumpf).

\section{Results}

\section{Comparison of people eligible for enrolment programs with the general population}

In Quebec, we identified 1569010 people eligible for the vulnerable enrolment program and 2394923 people eligible for the general enrolment program (Table 3). A total of 505869 people $(32.2 \%)$ were enrolled within the first 2 years under the vulnerable enrolment program and 352380 (14.7\%) within the first 2 years under the general enrolment program.

In BC, we identified 133589 people eligible for the Chronic disease incentive, 47619 for the Complex care incentive and 1349428 for A GP for Me (Table 4). Of these, 60764 (45.5\%), $28273(59.4 \%)$ and 1066714 (79.0\%), respectively, were enrolled within the first 2 years of program implementation.

People eligible for programs with health-related enrolment criteria (vulnerable enrolment in Quebec, Chronic disease incentive and Complex care incentive in BC) were older, had a higher average number of comorbidities and lived in lower-income neighbourhoods compared to the general population (Table 3, Table 4). They also had more primary care and emergency department visits and higher longitudinal continuity before enrolment than the general population (Table 3, Table 4, Table 5). Slightly higher proportions of people living outside metropolitan areas than those living elsewhere were eligible for programs with health-related eligibility criteria (data not shown).

In Quebec, the population eligible for the general enrolment program did not include people previously eligible under the vulnerable enrolment program. As a result, the eligible population was somewhat younger and had fewer comorbidities than the general population. In $\mathrm{BC}$, because analysis of A GP for Me was limited to people with 3 or more primary care visits for more reliable assignment, the study population was older and had more comorbidities than the general population (Table 4).

\section{Comparison of enrolled people with people who were eligible but not enrolled}

\section{Neighbourhood income quintile and income assistance}

People living in higher-income neighbourhoods were more likely than those living in lower-income neighbourhoods to be enrolled in programs without enrolment criteria (Quebec's general enrolment program and BC's A GP for Me) (Table 5). In $\mathrm{BC}$, those receiving income assistance had lower odds of enrolment than those not receiving income assistance (adjusted OR $0.76,95 \%$ confidence interval $[\mathrm{CI}]$ 0.75-0.78). For Quebec's vulnerable enrolment program, the relation with income was in the other direction: the odds of enrolment were somewhat lower among people who lived in the highest-income neighbourhoods than among those in the lowest-income neighbourhoods (adjusted OR 0.95, 95\% CI 0.94-0.96) (Table 5). 
Table 3: Demographic characteristics, comorbidities and use of health care services among the general population, patients enrolled and patients eligible but not enrolled within the first 2 years before program implementation in Quebec

\section{No. (\%) of people*}

\begin{tabular}{|c|c|c|c|c|c|c|c|}
\hline \multirow[b]{2}{*}{ Variable } & \multirow{2}{*}{$\begin{array}{c}\text { Population } \\
\text { aged } \geq 40 \text { yr† } \\
n=4043955\end{array}$} & \multicolumn{3}{|c|}{ Vulnerable enrolment } & \multicolumn{3}{|c|}{ General enrolment } \\
\hline & & $\begin{array}{c}\text { Enrolled } \\
n=505869\end{array}$ & $\begin{array}{c}\text { Not enrolled } \\
n=1063141\end{array}$ & $\begin{array}{l}\text { Standardized } \\
\text { differencef }\end{array}$ & $\begin{array}{c}\text { Enrolled } \\
n=352384\end{array}$ & $\begin{array}{c}\text { Not enrolled } \\
n=2042543\end{array}$ & $\begin{array}{c}\text { Standardized } \\
\text { difference }\end{array}$ \\
\hline Age group, yr & & & & -0.853 & & & -0.118 \\
\hline $40-49$ & 1399458 (34.6) & $33699(6.7)$ & $253701(23.9)$ & & $143111(40.6)$ & $946807(46.4)$ & \\
\hline $50-59$ & $1177884(29.1)$ & $68075(13.5)$ & $303729(28.6)$ & & $138721(39.4)$ & 740845 (36.3) & \\
\hline $60-69$ & $785691(19.4)$ & $107541(21.3)$ & $259932(24.4)$ & & $70552(20.0)$ & $354827(17.4)$ & \\
\hline $70-79$ & 457215 (11.3) & $218163(43.1)$ & $174997(16.5)$ & & NA & NA & \\
\hline$\geq 80$ & $220113(5.4)$ & 78391 (15.5) & $70774(6.7)$ & & NA & NA & \\
\hline Missing & $3594(0.1)$ & $0(0.0)$ & $8(0.0)$ & & $0(0.0)$ & $64(0.0)$ & \\
\hline Female sex & 2079367 (51.5) & $281512(55.7)$ & $603040(56.7)$ & -0.022 & $195164(55.4)$ & $957321(46.9)$ & -0.171 \\
\hline $\begin{array}{l}\text { No. of } \mathrm{ECl} \\
\text { categories, } \\
\text { mean } \pm \mathrm{SD}\end{array}$ & $0.57 \pm 0.87$ & $1.26 \pm 1.18$ & $0.80 \pm 1.00$ & 0.424 & $0.29 \pm 0.52$ & $0.22 \pm 0.48$ & 0.143 \\
\hline $\begin{array}{l}\text { Neighbourhood } \\
\text { income quintile }\end{array}$ & & & & -0.022 & & & -0.074 \\
\hline Q1 (lowest) & $802422(19.8)$ & $108911(21.5)$ & $223954(21.1)$ & & $59713(16.9)$ & $407162(19.9)$ & \\
\hline Q2 & $786080(19.4)$ & $103836(20.5)$ & $210634(19.8)$ & & $65660(18.6)$ & $381600(18.7)$ & \\
\hline Q3 & 781599 (19.3) & 95395 (18.9) & $196445(18.5)$ & & $72634(20.6)$ & $384663(18.8)$ & \\
\hline Q4 & 763762 (18.9) & $93118(18.4)$ & $192452(18.1)$ & & $73162(20.8)$ & 392944 (19.2) & \\
\hline Q5 (highest) & 778603 (19.3) & $88794(17.6)$ & $192457(18.1)$ & & $77909(22.1)$ & 392706 (19.2) & \\
\hline Missing & 131489 (3.3) & $15815(3.1)$ & $47199(4.4)$ & & $3306(0.9)$ & $83468(4.1)$ & \\
\hline Residence & & & & -0.124 & & & -0.077 \\
\hline Metropolitan & $2655942(65.7)$ & $298494(59.0)$ & $685284(64.4)$ & & $252526(71.7)$ & $1361442(66.7)$ & \\
\hline $\begin{array}{l}\text { Smaller } \\
\text { urban }\end{array}$ & $703685(17.4)$ & 112305 (22.2) & $180674(17.0)$ & & $51286(14.6)$ & $341448(16.7)$ & \\
\hline Rural/remote & $584843(14.5)$ & $86929(17.2)$ & $165944(15.6)$ & & 46765 (13.3) & $269430(13.2)$ & \\
\hline Missing & $99485(2.5)$ & $8141(1.6)$ & $31239(2.9)$ & & $1807(0.5)$ & $70223(3.4)$ & \\
\hline \multicolumn{8}{|c|}{ Use of health care services } \\
\hline Mental illness§ & $52357(1.3)$ & $10667(2.1)$ & 33934 (3.2) & -0.067 & NA & NA & \\
\hline $\begin{array}{l}\text { Substance use } \\
\text { disorderף }\end{array}$ & $19909(0.5)$ & $3352(0.7)$ & $12366(1.2)$ & -0.053 & NA & NA & \\
\hline $\begin{array}{l}\text { No. of primary } \\
\text { care visits, } \\
\text { mean } \pm \text { SD }^{\star \star}\end{array}$ & $3.26 \pm 5.48$ & $6.65 \pm 7.46$ & $4.28 \pm 5.85$ & 0.353 & $2.47 \pm 2.65$ & $1.80 \pm 2.73$ & 2.56 \\
\hline $\begin{array}{l}\text { No. of } \\
\text { emergency } \\
\text { department } \\
\text { visits, mean } \\
\pm \text { SD** }\end{array}$ & $0.53 \pm 1.69$ & $0.86 \pm 2.14$ & $0.68 \pm 1.99$ & 0.085 & $0.26 \pm 0.84$ & $0.25 \pm 0.87$ & 0.005 \\
\hline $\begin{array}{l}\text { Proportion of } \\
\text { visits with usual } \\
\text { care provider, } \\
\text { mean } \pm \text { SD }\end{array}$ & $0.59 \pm 0.43$ & $0.59 \pm 40.28$ & $0.38 \pm 41.92$ & 0.522 & $0.44 \pm 0.45$ & $0.25 \pm 0.40$ & 0.443 \\
\hline 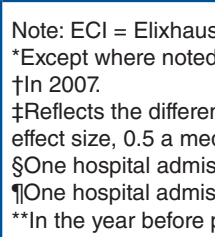 & $\begin{array}{l}\text { Comorbidity Index, } \mathrm{N} \\
\text { herwise. } \\
\\
\text { in means or proportic } \\
\mathrm{m} \text { effect size and } 0.8 \text { a } 2 \text { physician claim } \\
\text { on or } 1 \text { physician claim } \\
\text { gram implementation. }\end{array}$ & $\begin{array}{l}\text { = not applicable, } \mathrm{Q}= \\
\text { ns between people er } \\
\text { large effect size. } \\
\text { in the year before pr } \\
\text { in the year before pro }\end{array}$ & $\begin{array}{l}\text { quintile, } \mathrm{SD}=\text { standar } \\
\text { rolled and people elig } \\
\text { gram implementation } \\
\text { ram implementation. }\end{array}$ & $\begin{array}{l}\text { deviation. } \\
\text { e but not enrolle }\end{array}$ & consider a stan & lized difference of 0 . & be a small \\
\hline
\end{tabular}




\begin{tabular}{|c|c|c|c|c|c|c|c|c|c|c|}
\hline \multirow[b]{2}{*}{ Variable } & \multicolumn{10}{|c|}{ No. (\%) of people* } \\
\hline & $\begin{array}{c}\text { Population } \\
\text { aged } \geq 40 \text { yrt } \\
n=1953390\end{array}$ & $\begin{array}{c}\text { Enrolled } \\
n=60764\end{array}$ & $\begin{array}{l}\text { Not enrolled } \\
n=72825\end{array}$ & $\begin{array}{l}\text { Standardized } \\
\text { difference }\end{array}$ & $\begin{array}{c}\text { Enrolled } \\
n=28273\end{array}$ & $\begin{array}{l}\text { Not enrolled } \\
n=19346\end{array}$ & $\begin{array}{l}\text { Standardized } \\
\text { difference }\end{array}$ & $\begin{array}{c}\text { Enrolled } \\
n=1066714\end{array}$ & $\begin{array}{l}\text { Not enrolled } \\
n=282714\end{array}$ & $\begin{array}{l}\text { Standardized } \\
\text { difference }\end{array}$ \\
\hline $50-59$ & $\begin{array}{c}584379 \\
(29.9)\end{array}$ & $\begin{array}{c}14342 \\
(23.6)\end{array}$ & $\begin{array}{l}17356 \\
(23.8)\end{array}$ & & $\begin{array}{l}3222 \\
(11.4)\end{array}$ & $\begin{array}{l}3584 \\
(18.5)\end{array}$ & & $\begin{array}{c}290914 \\
(27.3)\end{array}$ & $\begin{array}{l}82109 \\
(29.0)\end{array}$ & \\
\hline $60-69$ & $\begin{array}{c}376210 \\
(19.3)\end{array}$ & $\begin{array}{l}17488 \\
(28.8)\end{array}$ & $\begin{array}{l}19244 \\
(26.4)\end{array}$ & & $\begin{array}{l}7089 \\
(25.1)\end{array}$ & $\begin{array}{l}5409 \\
(28.0)\end{array}$ & & $\begin{array}{c}276542 \\
(25.9)\end{array}$ & $\begin{array}{l}68406 \\
(24.2)\end{array}$ & \\
\hline $70-79$ & $\begin{array}{c}235635 \\
(12.1)\end{array}$ & $\begin{array}{l}16023 \\
(26.4)\end{array}$ & $\begin{array}{l}18116 \\
(24.9)\end{array}$ & & $\begin{array}{l}10160 \\
(35.9)\end{array}$ & $\begin{array}{l}5745 \\
(29.7)\end{array}$ & & $\begin{array}{c}179607 \\
(16.8)\end{array}$ & $\begin{array}{l}40170 \\
(14.2)\end{array}$ & \\
\hline $\begin{array}{l}\text { No. of } \mathrm{ECl} \\
\text { categories, mean } \\
\pm \mathrm{SD}\end{array}$ & $0.88 \pm 1.08$ & $2.13 \pm 1.25$ & $2.15 \pm 1.38$ & -0.02 & $3.25 \pm 1.66$ & $2.89 \pm 1.62$ & 0.22 & $1.39 \pm 1.26$ & $1.27 \pm 1.21$ & 0.09 \\
\hline $\begin{array}{l}\text { Neighbourhood } \\
\text { income quintile }\end{array}$ & & & & 0.03 & & & 0.03 & & & 0.20 \\
\hline Q1 (lowest) & $\begin{array}{c}368926 \\
(18.9)\end{array}$ & $\begin{array}{l}13952 \\
(23.0)\end{array}$ & $\begin{array}{l}17393 \\
(23.9)\end{array}$ & & $\begin{array}{l}6793 \\
(24.0)\end{array}$ & $\begin{array}{l}4850 \\
(25.1)\end{array}$ & & $\begin{array}{l}195711 \\
(18.3)\end{array}$ & $\begin{array}{l}65901 \\
(23.3)\end{array}$ & \\
\hline Q2 & $\begin{array}{c}374503 \\
(19.2)\end{array}$ & $\begin{array}{l}12654 \\
(20.8)\end{array}$ & $\begin{array}{l}15257 \\
(21.0)\end{array}$ & & $\begin{array}{l}6193 \\
(21.9)\end{array}$ & $\begin{array}{l}4293 \\
(22.2)\end{array}$ & & $\begin{array}{c}205854 \\
(19.3)\end{array}$ & $\begin{array}{l}63655 \\
(22.5)\end{array}$ & \\
\hline Q3 & $\begin{array}{c}387101 \\
(19.8)\end{array}$ & $\begin{array}{l}11788 \\
(19.4)\end{array}$ & $\begin{array}{l}13716 \\
(18.8)\end{array}$ & & $\begin{array}{l}5488 \\
(19.4)\end{array}$ & $\begin{array}{l}3749 \\
(19.4)\end{array}$ & & $\begin{array}{c}212035 \\
(19.9)\end{array}$ & $\begin{array}{c}54539 \\
(19.3)\end{array}$ & \\
\hline Q4 & $\begin{array}{c}391346 \\
(20.0)\end{array}$ & $\begin{array}{c}10632 \\
(17.5)\end{array}$ & $\begin{array}{l}12109 \\
(16.6)\end{array}$ & & $\begin{array}{l}4977 \\
(17.6)\end{array}$ & $\begin{array}{l}3352 \\
(17.3)\end{array}$ & & $\begin{array}{c}219252 \\
(20.6)\end{array}$ & $\begin{array}{c}49942 \\
(17.7)\end{array}$ & \\
\hline Smaller urban & $\begin{array}{c}449767 \\
(23.0)\end{array}$ & $\begin{array}{l}17308 \\
(28.5)\end{array}$ & $\begin{array}{l}18109 \\
(24.9)\end{array}$ & & $\begin{array}{l}7830 \\
(27.7)\end{array}$ & $\begin{array}{l}4196 \\
(21.7)\end{array}$ & & $\begin{array}{c}278942 \\
(26.1)\end{array}$ & $\begin{array}{c}33312 \\
(11.8)\end{array}$ & \\
\hline Rural/remote & $\begin{array}{l}221884 \\
(11.4)\end{array}$ & $\begin{array}{l}6049 \\
(10.0)\end{array}$ & $\begin{array}{l}9161 \\
(12.6)\end{array}$ & & $\begin{array}{l}2630 \\
(9.3)\end{array}$ & $\begin{array}{l}2858 \\
(14.8)\end{array}$ & & $\begin{array}{c}116952 \\
(11.0)\end{array}$ & $\begin{array}{c}20501 \\
(7.3)\end{array}$ & \\
\hline Missing & $\begin{array}{l}5873 \\
(0.3)\end{array}$ & $\begin{array}{l}106 \\
(0.2)\end{array}$ & $\begin{array}{l}140 \\
(0.2)\end{array}$ & & $\begin{array}{c}6 \\
(0.0)\end{array}$ & $\begin{array}{c}7 \\
(0.0)\end{array}$ & & $\begin{array}{l}238 \\
(0.0)\end{array}$ & $\begin{array}{c}74 \\
(0.0)\end{array}$ & \\
\hline \multicolumn{11}{|c|}{ Use of health care services } \\
\hline Mental illness & $\begin{array}{c}179352 \\
(9.2)\end{array}$ & $\begin{array}{l}5846 \\
(9.6)\end{array}$ & $\begin{array}{l}7382 \\
(10.1)\end{array}$ & -0.02 & $\begin{array}{l}3379 \\
(12.0)\end{array}$ & $\begin{array}{l}2588 \\
(13.4)\end{array}$ & -0.04 & $\begin{array}{c}143376 \\
(13.4)\end{array}$ & $\begin{array}{l}33874 \\
(12.0)\end{array}$ & 0.04 \\
\hline $\begin{array}{l}\text { Substance use } \\
\text { disorder }\end{array}$ & $\begin{array}{c}23538 \\
(1.2)\end{array}$ & $\begin{array}{l}582 \\
(1.0)\end{array}$ & $\begin{array}{l}1029 \\
(1.5)\end{array}$ & -0.04 & $\begin{array}{l}551 \\
(1.9)\end{array}$ & $\begin{array}{l}597 \\
(3.1)\end{array}$ & -0.07 & $\begin{array}{c}18671 \\
(1.8)\end{array}$ & $\begin{array}{l}8077 \\
(2.9)\end{array}$ & -0.07 \\
\hline $\begin{array}{l}\text { No. of primary } \\
\text { care visits, mean } \\
\pm \text { SD }\end{array}$ & $5.58 \pm 7.02$ & $10.09 \pm 7.91$ & $9.97 \pm 8.58$ & 0.01 & $14.34 \pm 10.17$ & $12.69 \pm 10.40$ & 0.16 & $7.45 \pm 6.48$ & $7.78 \pm 8.11$ & -0.06 \\
\hline $\begin{array}{l}\text { No. of emergency } \\
\text { department visits, } \\
\text { mean } \pm \text { SD }\end{array}$ & $0.28 \pm 1.06$ & $0.43 \pm 1.30$ & $0.52 \pm 1.34$ & -0.07 & $1.26 \pm 2.32$ & $1.33 \pm 2.59$ & -0.03 & $0.48 \pm 1.36$ & $0.46 \pm 1.43$ & 0.02 \\
\hline $\begin{array}{l}\text { Proportion of visits } \\
\text { with usual care } \\
\text { provider, mean } \\
\pm \text { SD }\end{array}$ & $0.80 \pm 0.22$ & $0.84 \pm 0.18$ & $0.83 \pm 0.19$ & 0.05 & $0.82 \pm 0.18$ & $0.80 \pm 0.20$ & 0.10 & $0.80 \pm 0.22$ & $0.78 \pm 0.24$ & 0.09 \\
\hline $\begin{array}{l}\text { Note: } \mathrm{ECl}=\text { Elixhau } \\
{ }^{\circ} \text { Except where note } \\
\text { †In } 2007 . \\
\ddagger \text { As indicated by pre }\end{array}$ & $\begin{array}{l}\text { ser Comorbidity } \\
\text { d otherwise. }\end{array}$ & $\begin{array}{l}\text { Index, NA = nc } \\
\text { overage. }\end{array}$ & & & & & & & & \\
\hline
\end{tabular}


Research

\begin{tabular}{|c|c|c|c|c|c|c|}
\hline \multirow[b]{2}{*}{ Variable } & \multicolumn{2}{|c|}{ Vulnerable enrolment; OR (95\% Cl) } & \multicolumn{2}{|c|}{ General enrolment; OR (95\% Cl) } & & \\
\hline & Crude & Adjusted & Crude & Adjusted & & \\
\hline \multicolumn{7}{|l|}{ Quebec } \\
\hline Q3 & $1.00(0.99-1.01)$ & $1.04(1.03-1.05)$ & $1.19(1.18-1.21)$ & $1.18(1.16-1.19)$ & & \\
\hline Q4 & $1.00(0.98-1.01)$ & $1.04(1.03-1.06)$ & $1.20(1.19-1.21)$ & $1.18(1.17-1.20)$ & & \\
\hline Q5 (highest) & $0.95(0.94-0.96)$ & $0.95(0.94-0.96)$ & $1.23(1.22-1.24)$ & $1.21(1.20-1.23)$ & & \\
\hline \multicolumn{7}{|l|}{ Residence (Ref: metropolitan) } \\
\hline Smaller urban & $1.43(1.42-1.44)$ & $1.62(1.60-1.63)$ & $0.81(0.80-0.82)$ & $0.76(0.79-0.80)$ & & \\
\hline \multirow[t]{2}{*}{ Substance use disorder } & $0.57(0.55-0.59)$ & $0.60(0.58-0.63)$ & NA & NA & & \\
\hline & \multicolumn{2}{|c|}{ Chronic disease incentive; OR $(95 \% \mathrm{Cl})$} & \multicolumn{2}{|c|}{ Complex care incentive; OR (95\% Cl) } & \multicolumn{2}{|c|}{ A GP for Me; OR (95\% Cl) } \\
\hline Variable & Crude & Adjusted & Crude & Adjusted & Crude & Adjusted \\
\hline \multicolumn{7}{|l|}{ British Columbia } \\
\hline \multicolumn{7}{|c|}{ Neighbourhood income quintile (Ref: Q1 [lowest]) } \\
\hline Q2 & $1.03(1.00-1.07)$ & $1.03(0.99-1.06)$ & $1.03(0.98-1.09)$ & $1.02(0.97-1.08)$ & $1.09(1.08-1.10)$ & $1.09(1.08-1.11)$ \\
\hline Q3 & $1.07(1.04-1.11)$ & $1.06(1.03-1.10)$ & $1.05(0.99-1.10)$ & $1.05(0.99-1.11)$ & $1.31(1.29-1.33)$ & $1.33(1.31-1.34)$ \\
\hline Q4 & $1.09(1.06-1.13)$ & $1.09(1.05-1.12)$ & $1.06(1.00-1.12)$ & $1.06(1.00-1.13)$ & $1.48(1.46-1.50)$ & $1.50(1.48-1.52)$ \\
\hline Mental illness & $0.94(0.91-0.98)$ & $0.98(0.94-1.02)$ & $0.88(0.83-0.93)$ & $0.87(0.82-0.93)$ & $1.14(1.13-1.16)$ & $1.14(1.13-1.16)$ \\
\hline Substance use disorder & $0.67(0.61-0.75)$ & $0.72(0.65-0.80)$ & $0.62(0.56-0.70)$ & $0.64(0.56-0.72)$ & $0.61(0.59-0.62)$ & $0.61(0.59-0.63)$ \\
\hline
\end{tabular}

\section{Residence}

There was no consistent pattern of enrolment by urban versus rural residence. In Quebec's vulnerable enrolment program, the odds of enrolment were higher among people outside metropolitan areas than those in metropolitan areas, whereas the reverse was true for the general enrolment program. In the $\mathrm{BC}$ programs with eligibility criteria, people who lived in smaller urban areas were more likely to be enrolled than those in metropolitan areas. In the A GP for Me program, people living outside metropolitan areas had higher odds of having a primary care provider who participated in the enrolment program than those living in metropolitan areas.

\section{Mental illness and substance use disorders}

The odds of enrolment among people who received mental health services before enrolment were somewhat lower than among those who did not (adjusted OR 0.87-0.98) with the exception of A GP for Me (adjusted OR 1.14, 95\% CI 1.131.16). People who had received services for a substance use disorder had lower odds of enrolment than those who had not across all programs (adjusted OR 0.60-0.72).

Service use in the year before program implementation In Quebec, having made additional visits to primary care in the year before enrolment was associated with higher odds of enrolment (adjusted OR 1.03-1.06) (Table 6). In BC, the odds of enrolment did not differ by number of primary care visits. For the vulnerable enrolment program in Quebec, having made additional emergency department visits in the year before enrolment was associated with higher odds of enrolment (adjusted OR 1.04, 95\% CI 1.04-1.04). In all other programs, the number of emergency department visits 


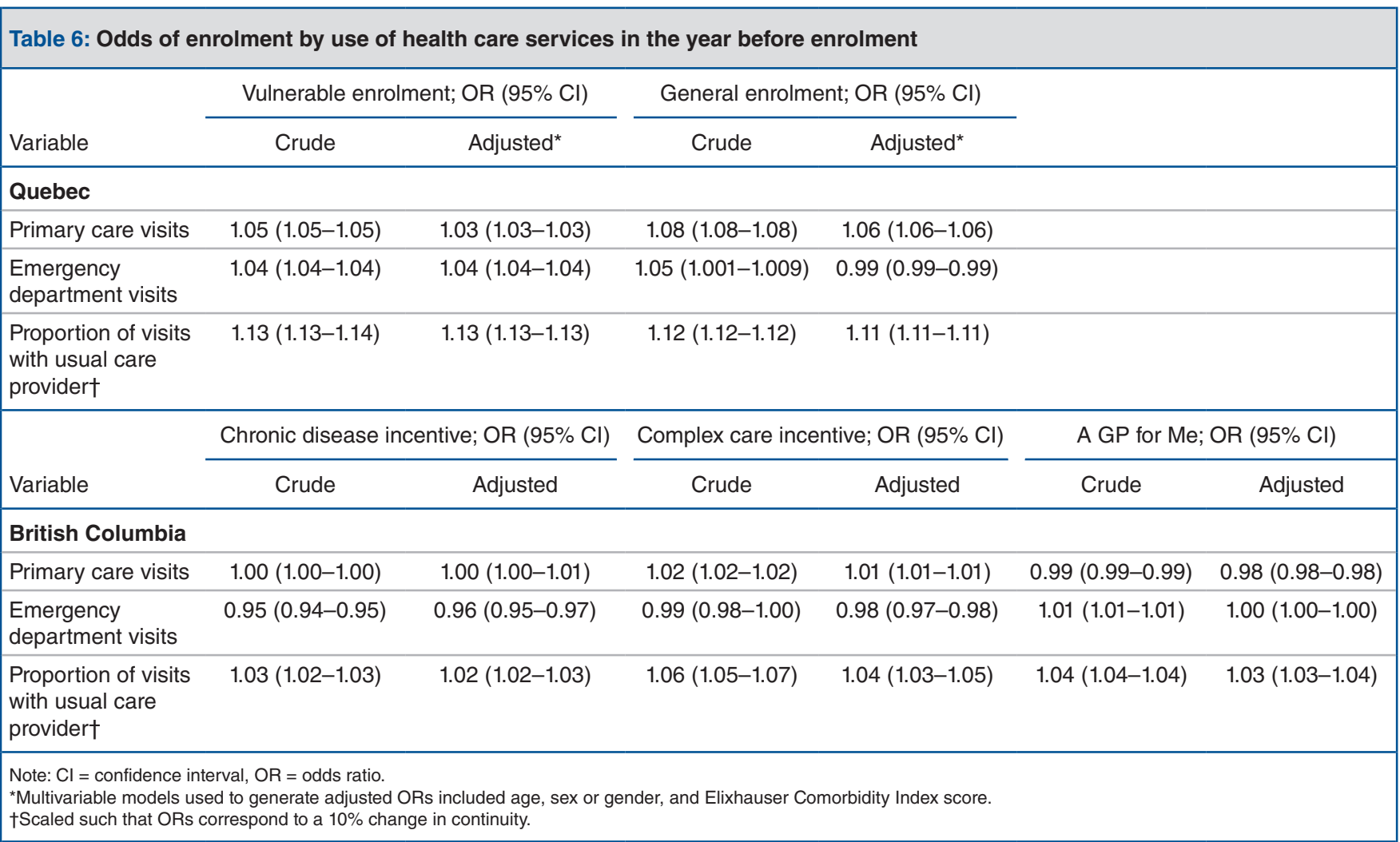

in the prior year was not associated with odds of enrolment. In both provinces, people with higher longitudinal continuity in the year before enrolment had higher odds of enrolment (adjusted OR per 10\% change in continuity 1.02-1.13).

\section{Interpretation}

In the context of voluntary enrolment programs introduced within fee-for-service payment, people who lived in higherincome neighbourhoods were more likely to be enrolled than those in lower-income neighbourhoods, especially in programs with no health-related eligibility criteria. The odds of enrolment by urban-rural location varied. People who had received services for mental illness or substance use disorders in the year before enrolment generally had lower odds of enrolment. Greater continuity of care in the year before enrolment was associated with slightly higher odds of enrolment, as was the number of primary care visits in the year before enrolment in Quebec.

Our findings with respect to enrolment by neighbourhood income are consistent with previous research. ${ }^{22-26}$ Our observation that people who were previously treated for mental illness and substance use disorders were less likely to be enrolled than those who had not received such treatment is consistent with literature documenting barriers to accessing primary care for these patients. ${ }^{16-18}$

Our finding that, compared to people eligible but not enrolled, people enrolled tended to have similar or higher numbers of primary care visits and longitudinal continuity of care in the year before enrolment suggests that enrolment programs may formalize existing care relationships between patients and providers, or that presenting at a practice more often may increase the chance of enrolment. ${ }^{27}$

\section{Limitations}

It is possible that people enrolled in the 2 years after program implementation differed from those who would later be enrolled. Another analysis that included a broader range of programs targeting chronic conditions showed that physician participation in enrolment programs stabilized after the first 2 years, ${ }^{27}$ but including only 2 years is a limitation of the present analysis. By using measures of treatment for mental illness and substance use disorder, we missed people who did not seek care and who may have had the greatest need for primary care enrolment. Similarly, we assessed eligibility criteria for the programs using diagnostic codes recorded in billing data. Although this accurately reflects people who would be confirmed eligible by funders, there may have been people whose conditions were not recorded and who would have otherwise been eligible for the programs.

There is the potential for geographic clustering that is not accounted for in our analysis, although we observed little variation in enrolment among regions. We cannot determine whether the patterns observed reflect physician choices about which patients to enrol or simply the characteristics of patients who already had relationships with physicians. Furthermore, although programs used billing codes to formalize 
enrolment between physicians and payers, this may not have been confirmed with patients. The effect of enrolment programs on access to or quality of care is therefore uncertain and requires further scrutiny. Regardless of this effect, the substantial investments in enrolment programs appear to have compensated physicians for providing services to patients from disproportionately more affluent areas.

\section{Conclusion}

In both BC and Quebec, people living in lower-income neighbourhoods were less likely than people in higher-income neighbourhoods to be enrolled in voluntary enrolment programs open to the general population. Across all programs, people treated for substance use disorders were less likely than those not treated for such disorders to be enrolled. When enrolment programs had health-related eligibility criteria, the odds of enrolment were similar across income groups. Voluntary programs do not appear to promote enrolment for groups that often experience lower access to primary care. Other strategies to promote equity in access to primary care are needed.

\section{References}

1. Haggerty JL, Reid RJ, Freeman GK, et al. Continuity of care: a multidisciplinary review. BM7 2003;327:1219-21.

2. Tiagi R, Chechulin Y. The effect of rostering with a patient enrolment model on emergency department utilization. Healtbc Policy 2014;9:105-21.

3. Bodenheimer T, Ghorob A, Willard-Grace R, et al. The 10 building blocks of high-performing primary care. Ann Fam Med 2014;12:166-71.

4. Roland M, Guthrie B, Thomé DC. Primary medical care in the United Kingdom. 7 Am Board Fam Med 2012;25(Suppl 1):S6-11.

5. Dahrouge S, Hogg W, Russell G, et al. The Comparison of Models of Primary Care in Ontario (COMP-PC) Study: methodology of a multifaceted crosssectional practice-based study. Open Med 2009;3:e149-64.

6. Best advice: patient rostering in family practice. Mississauga (ON): College of Family Physicians of Canada; 2012.

7. Entente particulière GMF intégrant les clientèles vulnérables. Régie de l'assurance maladie, Ministère de la Santé et des Services sociaux; 2003. Available: https://waext.banq.qc.ca/wayback/20061228043257/http://www.ramq.gouv. qc.ca/fr/professionnels/comm/2003/com032-3.pdf (accessed 2019 Jan. 15).

8. E.P. - Services de médecine de famille, de prise en charge et de suivi de la clientèle: inscription générale de la clientèle. Québec: Régie de l'assurance maladie; 2008. Available: https://www.ramq.gouv.qc.ca/sitecollectiondocuments/ professionnels/infolettres/2008/com145-8.pdf (accessed 2019 Jan. 10).

9. Amendement no. 116 et Lettre d'entente no. 228: Modification à votre entente et changements tarifaires au $1^{\text {er }}$ octobre 2010. Québec: Régie de l'assurance maladie; 2010. Available: https://www.ramq.gouv.qc.ca/SiteCollectionDocuments/ professionnels/infolettres/2010/info124-0.pdf (accessed 2019 Jan. 20).

10. Lavergne MR, Law MR, Peterson S, et al. Effect of incentive payments on chronic disease management and health services use in British Columbia, Canada: interrupted time series analysis. Health Policy 2018;122:157-64.

11. Lavergne MR, Law MR, Peterson S, et al. A population-based analysis of incentive payments to primary care physicians for the care of patients with complex disease. CMA7 2016;188:E375-83.

12. Cavers B. Attachment: how "A GP for Me" will help improve BC's primary care system. BCM7 2013;55:160.

13. Dahrouge $\mathrm{S}$, Hogg $W$, Muggah E, et al. Equity of primary care service delivery for low income "sicker" adults across 10 OECD countries. Int 7 Equity Health 2018; $17: 182$

14. Corscadden L, Levesque JF, Lewis V, et al. Factors associated with multiple barriers to access to primary care: an international analysis. Int 7 Equity Health 2018;17:28.

15. Sibley LM, Weiner JP. An evaluation of access to health care services along the rural-urban continuum in Canada. BMC Health Serv Res 2011;11:20.

16. Kaufman EA, McDonell MG, Cristofalo MA, et al. Exploring barriers to primary care for patients with severe mental illness: frontline patient and provider accounts. Issues Ment Health Nurs 2012;33:172-80.

17. Knaak S, Mantler E, Szeto A. Mental illness-related stigma in healthcare: barriers to access and care and evidence-based solutions. Healthc Manage Forum 2017; 30:111-6.

18. Steele LS, Durbin A, Sibley LM, et al. Inclusion of persons with mental illness in patient-centred medical homes: cross-sectional findings from Ontario, Canada. Open Med 2013;7:e9-20.
19. Roberts KC, Rao DP, Bennett TL, et al. Prevalence and patterns of chronic disease multimorbidity and associated determinants in Canada. Health Promot Chronic Dis Prev Can 2015;35:87-94.

20. Lee DS, Chiu M, Manuel DG, et al.; Canadian Cardiovascular Outcomes Research Team. Trends in risk factors for cardiovascular disease in Canada: temporal, socio-demographic and geographic factors. CMAJ 2009;181: E55-66.

21. Olah ME, Gaisano G, Hwang SW. The effect of socioeconomic status on access to primary care: an audit study. CMA7 2013;185:E263-9.

22. Sibley LM, Glazier RH. Evaluation of the equity of age-sex adjusted primary care capitation payments in Ontario, Canada. Health Policy 2012;104: 186-92.

23. Glazier RH, Klein-Geltink J, Kopp A, et al. Capitation and enhanced fee-forservice models for primary care reform: a population-based evaluation. CMAJ 2009;180:E72-81.

24. Laberge M, Wodchis WP, Barnsley J, et al. Costs of health care across primary care models in Ontario. BMC Health Serv Res 2017;17:511.

25. Breton $M$, Brousselle A, Boivin A, et al. Who gets a family physician through centralized waiting lists? BMC Fam Pract 2015;16:10.

26. Borgès Da Silva R, Fiset-Laniel J, Hazra A, et al. Analyse d'une politique de santé visant l'amélioration de l'accès à un médecin de famille - les guichets d'accès pour la clientèle orpheline au Québec. Montréal: Centre interuniversitaire de recherche en analyse des organisations (CIRANO); 2015.

27. McGrail K, Lavergne MR, Ahuja M, et al. Patient and primary care physician characteristics associated with billing incentives for chronic diseases in British Columbia: a retrospective cohort study. CMA7 Open 2020;8:E319-27.

28. King C. Assessing the impacts of the Quebec primary care enrolment policies on patient-physician affiliation [dissertation]. Montreal: McGill University. 2021. Available: https://escholarship.mcgill.ca/concern/theses/8623j3825?locale=en (accessed 2022 Jan. 6).

29. British Columbia Ministry of Health. Medical Services Plan (MSP) payment information file [data abstract]. Vancouver: Population Data BC; 2011, updated 2018. Available: www.popdata.bc.ca/data/health/msp/.

30. Population and vital statistics: consolidation file (BC Ministry of Health Services Registration \& Premium Billing [R\&PB] files) [data extract]. Vancouver: Population Data BC; updated 2018 Nov. 18. Available: www.popdata.bc.ca/ data/population/consolidationfile/.

31. Canadian Institute for Health Information. Discharge Abstracts Database (hospital separations file) [data abstract]. Vancouver: Population Data BC; 2011, updated 2018. Available: www.popdata.bc.ca/data/health/dad/.

32. BC Vital Statistics Agency. Vital statistics deaths [data extract]. Vancouver: Population Data BC; 2011, updated 2018. Available: www.popdata.bc.ca/data/ population/.

33. PharmaNet; Data Stewardship Committee [data extract]. Vancouver: Population Data BC; 2011, updated 2018. Available: www.popdata.bc.ca/data/.

34. National Ambulatory Care Reporting System (NACRS) [data extract]. Vancouver: Population Data BC; 2011, updated 2018. Available: www.popdata.bc. $\mathrm{ca} /$ data/health/nacrs/

35. Elixhauser A, Steiner C, Harris DR, et al. Comorbidity measures for use with administrative data. Med Care 1998;36:8-27.

36. Statistical Area Classification (SAC). Ottawa: Statistics Canada; modified 2018 Sept. 17. Available: https://www150.statcan.gc.ca/n1/pub/92-195-x/2011001/ other-autre/sac-css/sac-css-eng.htm (accessed 2018 Sept. 15).

37. Yang D, Dalton JE. A unified approach to measuring the effect size between two groups using SAS. SAS conference proceedings: SAS Global Forum 2012; 2012 Apr. 22-25; Orlando, Fla.

Affiliations: Department of Family Medicine (Lavergne), Dalhousie University, Halifax, NS; Department of Epidemiology, Biostatistics and Occupational Health (King, Simon, Strumpf), McGill University, Montréal, Que.; Institut national d'excellence en santé et en services sociaux (King), Québec, Que.; Centre for Health Services and Policy Research (Peterson, McGrail), University of British Columbia, Vancouver, BC; Department of Family Medicine and Emergency Medicine (Hudon) and Faculty of Medicine and Health Sciences (Loignon), Université de Sherbrooke, Sherbrooke, Que.; Department of Family Practice (McCracken), University of British Columbia; Department of Family Medicine (McCracken), Providence Health Care; Patient Voices Network (Brackett), Vancouver, BC; Department of Economics (Strumpf), McGill University, Montréal, Que.

QC-BC Patient Enrolment Project Team: Megan Ahuja MPH, Zamzam Akbaraly DUT, Amélie Bouchard MSW, Jean-Marie Buregeya $\mathrm{PhD}$, Heather Davidson PhD, Jody Friesen MSc, Luc Germain MAS, Laurie Goldsmith $\mathrm{PhD}$, Thomas Gottin $\mathrm{PhD}$, Antoine Groulx MD MSc, Julie Fiset-Laniel BSc, France Légaré MD PhD, Marie-Thérèse Lussier MD MSc, Marie-Jo Ouimet MD, Marilyn Parker, Maxine Dumas Pilon MD, Ellen Randall MPH, Claude Richard MBA, Isabelle Samson MD 
Contributors: Ruth Lavergne and Erin Strumpf conceived of and designed the study. Erin Stumpf and Kim McGrail acquired the data. Ruth Lavergne oversaw data analysis and led drafting of the manuscript. Caroline King analyzed the Quebec data as part of a traineeship at the Institut national d'excellence en santé et en services sociaux. Sandra Peterson analyzed the data for British Columbia. All of the authors contributed to data interpretation, revised the manuscript critically for important intellectual content, approved the final version to be published, and agreed to be accountable for all aspects of the work.

Funding: This study was funded by the Canadian Institutes of Health Research Strategy for Patient Oriented Research (SPOR) Primary and Integrated Health Care Innovations Network (CIHR HCI 150578), the Michael Smith Foundation for Health Research (MSFHR 17268), McGill University, Réseau-1 Québec, the Quebec Ministère de la Santé et des Services sociaux and the Centre de recherche - Hôpital Charles-Le Moyne, Université de Sherbrooke. In-kind support was provided by the University of British Columbia and the Institut de recherche en santé publique, Université de Montréal. Ruth Lavergne is supported by a Michael Smith Foundation for Health Research Scholar Award, McGill University. Erin Strumpf is supported by a William Dawson Scholar Award, McGill University.
Content licence: This is an Open Access article distributed in accordance with the terms of the Creative Commons Attribution (CC BY-NC-ND 4.0) licence, which permits use, distribution and reproduction in any medium, provided that the original publication is properly cited, the use is noncommercial (i.e., research or educational use), and no modifications or adaptations are made. See: https://creativecommons.org/licenses/by-nc-nd/4.0/.

Data sharing: The data that support the findings of this study are approved for use by the respective data stewards in either province. In British Columbia, data were accessed through a process managed by Population Data BC (PopData). In Quebec, data were accessed as part of a traineeship at l'Institut national d'excellence en santé et en services sociaux (INESSS). The data sets used for this study will be archived, and requests for access to them in the context of verification of study findings can be made to PopData (https:// www.popdata.bc.ca/data_access) and INESSS. The authors are not permitted to share the research extract used in this analysis with other researchers.

Disclaimer: All inferences, opinions and conclusions drawn in this manuscript are those of the authors and do not reflect the opinions or policies of the data steward(s).

Supplemental information: For reviewer comments and the original submission of this manuscript, please see www.cmajopen.ca/content/10/ 1/E64/suppl/DC1. 